J. Clin. Chem. Clin. Biochem.

Vol. 20, 1982, pp. $571-574$

\title{
Determination of Ammonia in Saliva Using Indophenol, an Ammonium Electrode and an Enzymatic Method:
}

\section{A Comparative Investigation}

\author{
By J. R. Huizenga and C. H. Gips
}

Hepatochemical Laboratory, Division of Hepatology, Department of Medicine, University Hospital, Groningen, The Netherlands

(Received October 26, 1981/April 22, 1982)

Summary: Three methods for determination of ammonia in saliva are reported. The indophenol method on diluted saliva has the best precision (coefficient of variation $0.8 \%$ ) and the lowest reagent cost. The ammonium electrode method is the quickest, but it requires simultaneous determination of the potassium content of the specimen. The enzymatic method gives the same result as the electrode method, but is more expensive. Deproteinisation proved not to be necessary. In one hour 10,20 or 40 determinations can be performed 'with the enzymatic, indophenol- or the electrode method, respectively.

\section{Bestimmung von Ammoniak im Speichel mit der Berthelot-Reaktion, einer Ammonium-Elektrode und einer enzymatischen Methode: Eine vergleichende Untersuchung}

Zusammenfassung: Drei Methoden zur Bestimmung von Ammoniak im Speichel wurden geprüft. Die Methode nach Berthelot für verdünnten Speichel hat die beste Präzision (VK $=0,8 \%)$ und die geringsten Reagenzienkosten. Die Messung mit der Ammoniak-Elektrode ist die schnellste, erfordert jedoch die gleichzeitige Kalium-Bestimmung. Die enzymatische Methode ergibt die gleichen Resultate wie die potentiometrische, ist jedoch teurer. Enteiweißung ist nicht erforderlich. In einer Stunde können mit der enzymạtischen Methode 10, mit der Berthelot-Reaktion 20 und mit der potentiometrischen Methode 40 Bestimmungen dụrchgeführt werden.

\section{Introduction}

In the past few decades, salivary ammonia has received much attention in dentistry as it might have a role in prevention of caries (1). Salivary ammonia has been investigated in patients with chronic renal insufficiency, where it was found to be elevated (2).

The ammonia content of saliva is increased by bacterial hydrolysis of urea in salivary glands and oral cavity (3). Saliva must therefore be collected while it is flowing rapidly (e.g. after chewing gum) from a clean mouth.

The determination of ammonia in saliva has been described using aeration (4), ion-exchange chromatography - i.e. the method of Folin-Bell - $(5-10)$, microdiffusion $(1,11-13)$, distillation in vacuo (14) and common distillation $(15,16)$.

We have tried to develop simple methods for the determination of ammonia in saliva. Berthelot's indophenol reaction (17) was used after manifold dilution of saliva, to eliminate the effect of inhibitors $(18,19)$. An ammonium electrode method (20) was also tested. Lastly, the use of an enzymatic method (21), based on the conversion of 2-oxoglutarate and $\mathrm{NH}_{4}^{+}$to $L$-glutamate, was investigated. As deproteinisation might have an effect on the ammonia level measured, we tested both uranylacetate and trichloroacetic acid.

The preservation of saliva for ammonia determination has been dealt with elsewhere (22).

\section{Materials and Methods}

Twice distilled water was used throughout. Fresh saliva was obtained after chewing gum, followed by thorough rinsing of the mouth with water. The determinations were performed on freshly voided saliva samples. Because of the high ammonia content of saliva, manifold dilution (1:100) was necessary for the indophenol and enzymatic methods. The electrode method needed dilution of the saliva sample to obtain enough volume for measurement. 


\section{Indophenol method}

\section{Apparatus}

Test tubes (glass, $10 \mathrm{ml}$ ); $1 \mathrm{ml}$ volume pipettes; 2 Pipettors ${ }^{\circledR}$ (Oxford Laboratories, models SA, $1000 \mathrm{ml}$, and $\mathrm{R}, 500 \mathrm{ml}$, respectively); dark $37^{\circ} \mathrm{C}$ waterbath; colorimeter (Vitatron $\mathrm{DCP}, 623 \mathrm{~nm}$ filter).

\section{Reagents (23)}

Solution A: $5 \mathrm{~g}$ phenol, $4 \mathrm{~g} \mathrm{NaOH}$ pellets and $2 \mathrm{ml}$ sodium nitroprusside $10 \mathrm{~g} / 1$, made up with water to $400 \mathrm{ml}$.

Solution B: the contents of a $10 \mathrm{ml}$ ampoule containing $0.2 \mathrm{~mol} / 1$ sodium hypochlorite is made up with water to $100 \mathrm{ml}$.

Reagent blank: water. Stock standard: $23.4 \mathrm{mg}\left(\mathrm{NH}_{4}\right)_{2} \mathrm{SO}_{4}$ in $100 \mathrm{ml}$ water.

Standard solutions 50 and $100 \mu \mathrm{mol} \mathrm{NH}_{4}^{+} / 1: 1$ and $2 \mathrm{ml}$ of the stock standard are made up with water to $100 \mathrm{ml}$.

\section{Procedure}

1. Saliva, blank and standards are diluted $1: 100$

2. One $\mathrm{ml}$ of each of the dilutions is pipetted in test tubes.

3. $2 \mathrm{ml}$ of the phenolate-nitroprusside (A) and $1 \mathrm{ml}$ of the sodium hypochlorite solutions (B) are added and the mixture is immediately well shaken, and

4. incubated for 15 minutes in a dark waterbath at $37^{\circ} \mathrm{C}$.

5. Absorbance is read at $623 \mathrm{~nm}$

6. Calculation:

$$
\frac{\text { A sample }_{\text {sank }}-A_{\text {blank }}}{A_{\text {standard }}-A_{\text {blank }}} \times \text { standard }(\mathrm{mmol} / \mathrm{l})=\ldots \mathrm{mmol} / 1 \mathrm{NH}_{3}
$$

Ammonium electrode method

\section{Apparatus}

$10 \mathrm{ml}$ glass beakers; ammonium electrode (Philips IS560- $\mathrm{NH}_{4}$ ); reference electrode (Philips R44/2-SD/1); $\mathrm{pH}$ electrode (Philips C13-NS); digital voltmeter (Philips PW9414); flame photometer (Corning 450).

\section{Characteristics of the ammonium electrode}

Beyond $\mathrm{pH} 7$ the electrode shows a decline in potential (the $\mathrm{pH}$ of saliva is 6 ). Over a 24 hour period the drift of the potential, using a $1 \mathrm{mmol} / 1 \mathrm{NH}_{4} \mathrm{Cl}$ solution, was $3.5 \mathrm{mV}$. The electrode stability was better with water than with a buffer solution. The electrode response time (24) was 35 seconds.

The relationship between the electrode potential and the log $\left[\mathrm{NH}_{4}{ }^{+}\right]$was found to be linear between 1 and $10 \mathrm{mmol} / 1$ $\mathrm{NH}_{4}{ }^{+}$. The same correlation existed between electrode potential and $\log \left[\mathrm{K}^{+}\right]$, between 5 and $50 \mathrm{mmol} / 1 \mathrm{~K}^{+}$(fig. 1). As the

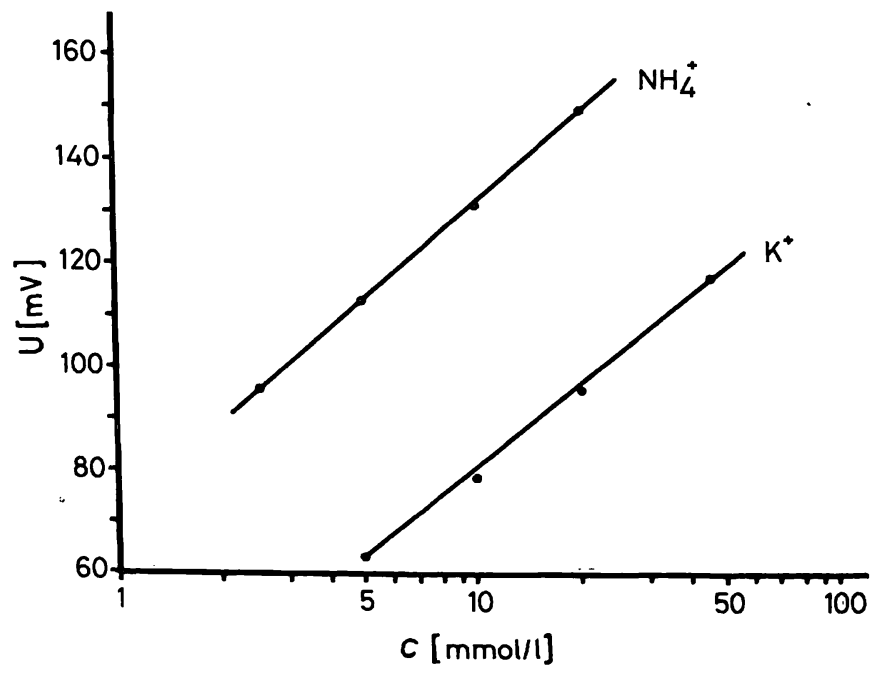

Fig. 1. Electrode response to a series of $\mathrm{NH}_{4}{ }^{+}$and $\mathrm{K}^{+}$concentrations. ammonium electrode measures potassium as well as ammonium (while we have not found any interference by other anions), correction for the potassium content has to take place (20). We have constructed (fig. 2) a nomogram by measuring the electrode potentials of series solutions with different ammonium and potassium concentrations. Use of the nomogram can be illustrated by the following example: When the non-corrected electrode potential gives a fictitious ammonium concentration of $7 \mathrm{mmol} / 1$ and when the potassium concentration is $20 \mathrm{mmol} / \mathrm{l}$, then the actual ammonium concentration will be $4.3 \mathrm{mmol} / 1$.

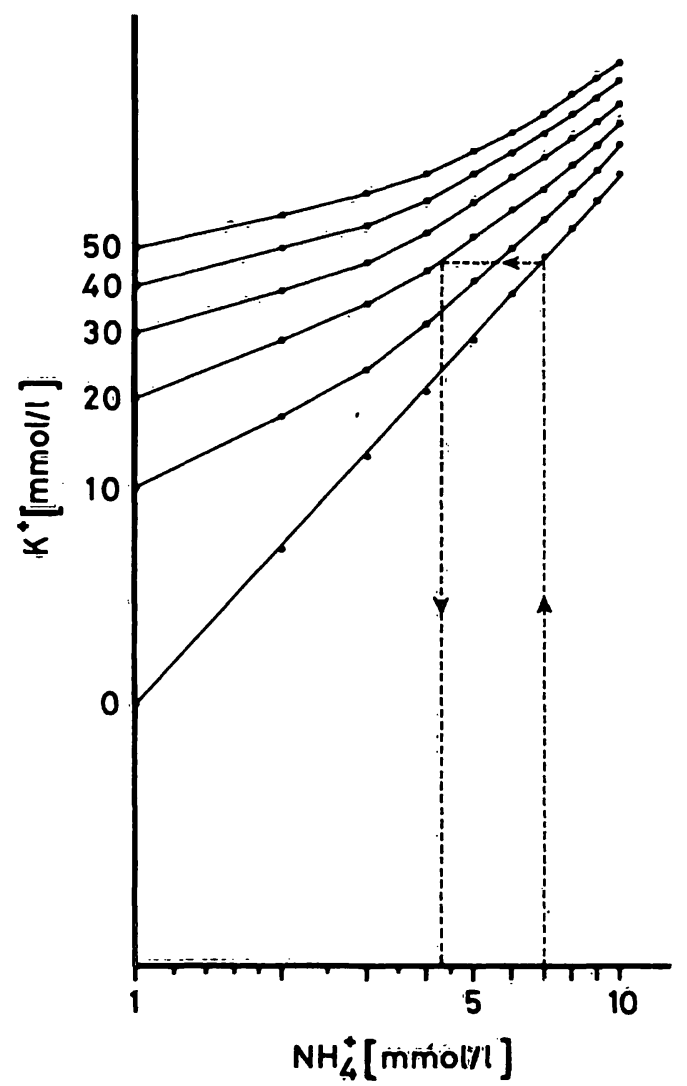

Fig. 2. Nomogram for determination of the actual salivary ammonia with the electrode method. See text for explanation of the example (broken lines).

\section{Procedure}

1. Standard solutions $2.5 ; 5.0 ; 10.0$ and $20.0 \mathrm{mmol} / 1 \mathrm{NH}_{3}$ are diluted $1: 10$ and an electrode standard curve is constructed.

2. Saliva is diluted $1: 10$ and the electrode potential is measured. This is the fictitious (non-corrected) ammonia concentration.

3. The potassium concentration of the saliva is measured with a flame photometer.

4. The actual ammonia concentration in saliva is determined using the nomogram (fig. 2).

\section{Enzymatic method}

Apparatus

Disposable cuvettes (Pharmaseal, cat. no. L $1045 \mathrm{M}$ ), 0.5 and 2.5 ml volume pipettes, $20 \mu$ l syringe (Hamilton); colorimeter (Vitatron DCP, $340 \mathrm{~nm}$ filter). 


\section{Solutions}

Solution C: $0.15 \mathrm{~mol} / 1$ triethanolamine buffer $\mathrm{pH} 8.6$.

Solution D: $15 \mathrm{mmol} / 1$ 2-oxoglutarate.

Solution E: $1.5 \mathrm{mmol} / 1$ ADP.

Solution F: $0.10 \mathrm{mmol} / 1 \mathrm{NADPH}$.

Solution G: $10 \mathrm{~g} / 1$ glutamate dehydrogenase suspension.

Reaction mixture: $20 \mathrm{ml} \mathrm{C,} 1 \mathrm{ml} \mathrm{D,} 2 \mathrm{ml} \mathrm{E}, 1 \mathrm{ml} \mathrm{F}$ and $6 \mathrm{ml}$ water.

Reagent blank (RB): water.

\section{Procedure}

$1.1 \mathrm{ml}$ saliva is diluted with water $1: 100$.

2. $2.5 \mathrm{ml}$ of the reaction mixture is pipetted into a cuvette and $0.5 \mathrm{ml}$ diluted saliva or $0.5 \mathrm{ml}$ reagent blank is added, mixed and the absorbance $A 1$ is measured after 10 minutes followed by

3. addition of $20 \mu l$ of solution $G$ and mixing.

4. After 10 minutes standing the absorbance $A 2$ is read.

5. Calculation:

$$
\begin{aligned}
& A 1-A 2=\Delta A_{\text {sample }} \text { or } \Delta A_{R B} \\
& \Delta A_{\text {sample }}-\Delta A_{R B}=\Delta A_{\text {corrected }}
\end{aligned}
$$

Concentration:

$96 \times \Delta \mathbf{A}_{\text {corrected }}=\ldots \mathrm{mmol} / 1 \mathrm{NH}_{3}$.

(Factor 96: $\frac{100 \times 6.04}{6.3}$. First dilution 100 times, second dilution 6.04 times.

Molar lineic absorbance of NADH $\left(30^{\circ} \mathrm{C}\right)$ is

$\epsilon 339 \mathrm{~mm}=630 \mathrm{~m}^{2} \cdot \mathrm{mol}^{-1}$

\section{Deproteinisation of saliva}

\section{Solutions}

Trichloroacetic acid $100 \mathrm{~g} / \mathrm{l}(0.61 \mathrm{~mol} / \mathrm{l})$.

Uranylacetate $1,6 \mathrm{~g} / 1(3.79 \mathrm{mmol} / \mathrm{l})$.

\section{Procedure}

Saliva was deproteinized by trichloroacetic acid or uranylace tate $1+1$. The sediment was negligible.

After centrifugation the ammonia concentration was measured in the supernatant fluid using the indophenol and electrode methods as described above and the results were compared with those of non-deproteinized specimens.

\section{Stạtistical aṇalysis}

Statistical analysis was performed using the Wilcoxon signed rank test (25). A difference was accepted to be significant at the $\mathrm{p}<0.05$ level.

\section{Results}

\section{Precision}

The ammonia content was determined twenty times in one diluted saliva sample. The results are given in table 1. Precision was best with the indophenol method.

\section{Ammonia and potassium in saliva of healthy controls}

Ammonia and potassium were determined in saliva samples of 23 healthy controls (tab. 2). The median of
Tab. 1. Precision. Ammonia contents determined 20 times with three methods in one saliva sample.

\begin{tabular}{lllll}
\hline $\mathrm{n}=20$ & $\begin{array}{l}\text { Range } \\
(\mathrm{mmol} / \mathrm{l})\end{array}$ & $\begin{array}{l}\text { Mean } \\
(\mathrm{mmol} / \mathrm{l})\end{array}$ & $\begin{array}{l}\text { S.D. } \\
(\mathrm{mmol} / \mathrm{l})\end{array}$ & $\begin{array}{l}\mathrm{CV} \\
(\%)\end{array}$ \\
\hline Ammonia & & & & \\
$\begin{array}{l}\text { Indophenol } \\
\text { Electrode }\end{array}$ & $6.1-6.3$ & 6.2 & 0.05 & 0.8 \\
$\quad \begin{array}{l}\quad \text { (K-corrected) } \\
\text { Enzymatic }\end{array}$ & $6.9-7.8$ & 7.4 & 0.3 & 3.6 \\
\hline
\end{tabular}

Tab. 2. Ammonia and potassium contents determined with three methods in saliva samples from 23 healthy subjects.

\begin{tabular}{llll}
\hline & $\begin{array}{l}\text { Mean } \\
(\mathrm{mmol} / \mathrm{l})\end{array}$ & $\begin{array}{l}\text { Median } \\
(\mathrm{mmol} / \mathrm{l})\end{array}$ & $\begin{array}{l}\text { Range } \\
(\mathrm{mmol} / \mathrm{l})\end{array}$ \\
\hline Ammonia & & & \\
Indophenol & 4.8 & 4.5 & $1.1-12.3$ \\
$\begin{array}{l}\text { Electrode } \\
\quad\left(\mathrm{K}^{+} \text {-corrected) }\right.\end{array}$ & 4.0 & 3.5 & $1.4-12.1$ \\
$\begin{array}{l}\text { Enzymatic } \\
\text { Potassium }\end{array}$ & 4.4 & 3.9 & $1.1-12.0$ \\
\hline
\end{tabular}

ammonium concentration was about 4 and the median of potassium concentration about $18 \mathrm{mmol} / \mathrm{l}$ (flame photometry). There was no difference in results between the potentiometric and enzymatic methods $(p=0.2)$, while a higher concentration was measured with the indophenol method $(\mathrm{p} \leqslant 0.005)$.

\section{Recovery}

Saliva was diluted $1: 10$ with standard ammonia solutions containing 0.5 and $1.0 \mathrm{mmol} / \mathrm{l}$, which resulted in an addition per sample of 4.5 and $9.0 \mu \mathrm{mol}$ respectively. The ammonia concentration then was determined with all three methods in samples from the same 23 healthy controls (tab. 3). The recoveries with the indophenol method were higher than with the potentiometric and enzymatic methods (addition of $4.5 \mu \mathrm{mol} p \leqslant 0.005$ and of $9 \mu \mathrm{mol} p \leqslant 0.02)$. There was no difference in recovery between the potentiometric and enzymatic methods (addition of $4.5 \mu \mathrm{mol} \mathrm{p}=0.6$ and of $9 \mu \mathrm{mol}$ $p=0.9$ ). A small but significant difference was found between the 4.5 and $9.0 \mu \mathrm{mol}$ additions when the indophenol method was used $(\mathrm{p}<0.0001)$.

Tab. 3. Recoveries of ammonium added to saliva $(n=23)$

\begin{tabular}{|c|c|c|c|c|}
\hline Method & $\begin{array}{l}\text { Ammonia } \\
4.5 \mu \mathrm{mol} \\
\text { Range } \\
(\%)\end{array}$ & $\begin{array}{l}\text { addition } \\
\text { Mean } \\
\pm \text { S.D. } \\
(\%)\end{array}$ & 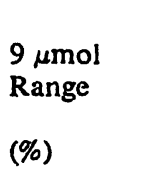 & $\begin{array}{l}\text { Mean } \\
\pm \text { S.D. } \\
(\%)\end{array}$ \\
\hline $\begin{array}{l}\text { Indophenol } \\
\text { Electrode } \\
\left(\mathbf{K}^{+} \text {-corrected }\right.\end{array}$ & $\begin{array}{l}91-109 \\
67-109 \\
\text { d) }\end{array}$ & $\begin{array}{r}100 \pm 5.2 \\
89 \pm 12.1\end{array}$ & $\begin{array}{l}87-107 \\
72-106\end{array}$ & $\begin{array}{l}96 \pm 5.7 \\
91 \pm 8.9\end{array}$ \\
\hline Enzymatic & $76-104$ & $90 \pm 7.7$ & $81-108$ & $91 \pm 6$ \\
\hline
\end{tabular}
using three methods. 


\section{Deproteinisation}

In saliva samples of two controls, the ammonia content was measured before and after deproteinisation with trichloroacetic acid and uranylacetate respectively (tab. 4). Deproteinisation resulted in a slightly lower ammonia level.

Tab. 4. The effect of deproteinisation of saliva on the ammonia measurement using the indophenol and $\left(\mathrm{K}^{+}\right.$-corrected) electrode methods $(\mathrm{mmol} / \mathrm{l})$.

\begin{tabular}{lll}
\hline Deproteinisation & Electrode method & Indophenol method \\
\hline No & 3.5 & 3.8 \\
Trichloroacetic acid & 3.3 & 3.7 \\
Uranylacetate & 3.2 & 3.6 \\
\hline
\end{tabular}

\section{Discussion}

Determination of salivary ammonia with one of these three methods is far easier than using any of the older procedures: The performance of all three methods is sufficient, but the indophenol method on diluted saliva has a better precision than both potentiometric and enzymatic methods and therefore is the method of choice for research work.

\section{References}

1. Regolati, B. (1971) Helv. Odont. Acta 15, suppl. VII, 139-146.

2. Baranmikova, J. A. (1977) Lab. Delo 11, 664-667.

3. Kopstein, J. \& Wrong, O. M. (1977) Clin. Sci. Mol. Med. 52, 9-17.

4. White, J. \& Bunting, R. W. (1935) J. Am. Dent. Ass. 22, $468-473$.

5. Ludwick, W. E. \& Fosdick, L. S. (1950) J. Dent. Res. 29, 38-42.

6. Grove, C. J. \& Grove, C. T. (1935) J. Am. Dent. Ass. 22, 247-252.

7. Jacobson, M. \& Kesel, R. G. (1950) J. Dent. Res. 29, $364-385$.

8. Hench, P. S. \& Aldrich, B. A. (1922) J. Am. Med. Ass. 79, 1409-1412.

9. Clegg, C. T. \& Rae, J. J. (1956) J. Dent. Res. 35, 438-439.

10. Folin, O. \& Bell, R. D. (1917) J. Biol. Chem. 29, 329-335.

11. Biswas, S. D. \& Kleinberg, I. (1971) Arch. Oral. Biol. 16, 759-777.

12. Wright, D. E. \& Jenkins, G. N. (1953) J. Dent. Res. 32, $232-238$

13. Jenkins, G. N. \& Wright, D. E. (1951) Brit. Dent. J. 90, $117-130$.
Some economical aspects are summarized in table 5 . The electrode method is rapid and cheap when large numbers of determinations have to be performed over a short period (the operational life of the membrane is about 4 weeks). The enzymatic method is the most laborious and expensive of the three. As the larger part of the equipment used will be available in a routine clinical chemistry laboratory, the cost of apparatus has not been included in our considerations.

Tab. 5. Economic aspects of the three ammonia determinations.

\begin{tabular}{lll}
\hline & $\begin{array}{l}\text { Parallel } \\
\text { determinations } \\
\text { per hour possible }\end{array}$ & Reagent costs \\
& $(\$)$ \\
\hline Indophenol & 20 & $0.02 /$ determination \\
Electrode & 40 & 33 per membrane \\
Enzymatic & 10 & $2.50 /$ determination \\
\hline
\end{tabular}

\section{Acknowledgement}

We wish to thank Mrs. M. L. Bunschoten-Pie and Mrs. $J$. G. Riksman for providing secretarial assịstannce. The figures were prepared by Mr. J. Brouwer.
14. Frank, R. (1929) Dtsch. Monatschr. f. Żahnhk. 47̄, 657-673.

15. Wurster, C. (1889) Ber. Dtsch. Chem. Ges. 22, 1901-1912.

16. Frostell, G. (1960) Acta Odont. Scand. 18, 29-65.

17. Berthelot, M. (1859) Répert. Chim :Appl., 284.

18. Gips, C. H. \& Reitsema, A. (1971) Clin. Chim. Acta 33, 257-259.

19. Gips, C. H., Reitsema, A. \& Wibbens-Alberts, M. (1970) Clin. Chim. Acta 29, 501-505.

20. Hoge, J. H. C., Hazenberg, H. J. A. \& Gips, C. H. (1974) Clin. Chim. Acta 55, 273-279.

21. Da Fonseca-Wollheim, F. (1973) Z. Klin. Chem. Klini. Bio= chem. $11,421-431$.

22. Huizenga, J. R. \& Gips, C. H. (1982) Clin. Chim. Acta 121; $399-402$.

23. Gips, C. H. \& Wibbens-Alberts, M. (1968) Clin. Chim. Acta $22,183-186$.

24. Philips Industries (1973) Guide to the use of ion selective electrodes. Liquid membrane IS560 series, 1-48 Philips Industries, Eindhoven.

25. Rümke, C. L. \& Van Eeden, C. (1961) De tekentoets en de symmetrietoets van Wilcoxon. In Statistiek voor Medici, 51-59. Stafleu en Zoon, Leiden.

J. R. Huizenga

Hepatochem. Lab., Div. of Hepatol. Dept. of Med., Univ. Hospital Oostersingel 59 NL-9713 EZ Groningen 